\title{
The Living Sign. Reading Noble from a Biosemiotic Perspective
}

\author{
Jos de Mul $^{1}$
}

Received: 12 March 2021 / Accepted: 14 April 2021 / Published online: 6 May 2021

(C) The Author(s) 2021

\begin{abstract}
The author argues that the reductionist illusions of the Modern Synthesis, which Noble criticizes in his target article, are to a large extent resulting from a mere syntactical notion of biological information, neglecting the pragmatic and semantic dimension of information. Although the syntactical notion, introduced by Shannon, has been applied with much success in information theory and computer technologies, it is too narrow to understand biological reality. Biosemiotics can help to clarify the problems identified by Noble, and offers a more adequate biological information concept, which not only may help to overcome these problems in the life sciences, but may also serve to integrate natural-scientific and humanities approaches to life.
\end{abstract}

Keywords Biosemiotics $\cdot$ Noble $\cdot$ Living sign $\cdot$ Syntactics $\cdot$ Pragmatics $\cdot$ Semantics

In his target article, Denis Noble refers to a possible bridge between his own work as a "biological scientist" and biosemiotics. In addition to the "few hints" regarding their mutual relevance mentioned by Noble, I would like to add another hint in my contribution, focusing on biological information. Inspired by the computer-induced development of information theory (Shannon, 1948) and the first adequate description of DNA (Watson \& Crick, 1953), the concept of 'biological information' has become a key concept in molecular genetics, and with it terms like 'code', 'signal', 'communication', 'translation', and 'interpretation' have entered the life sciences. And while semiotics, building on the work of Peirce and Morris, originally found its applications mainly in

Jos de Mul

demul@esphil.eur.nl

1 Erasmus School of Philosophy, Erasmus University Rotterdam, Rotterdam, Netherlands 
the domain of linguistic and other cultural signs, with the development of biosemiotics in the past decades, its focus has expanded to the communication of information in and between living organisms as well, from the scale of endosemiotics (the bio-molecular and biochemical level of non-intentional signs, including signs between organs and cells in the body) up to the scale of the biosphere. ${ }^{1}$

Like biology, biosemiotics is not one. The term, introduced at the beginning of the 1960s, has become an umbrella term that refers to a number of related, partly overlapping, partly complementary, and partly competing approaches at the border of the natural sciences (the life sciences in particular) and the humanities (semiotics and hermeneutics in particular), such as Darwinian semiotics, semantic biology, zoosemiotics, and biohermeneutics. However, the following four postulates are shared by most biosemioticians (Barbieri, 2008; Kull et al., 2009; Plessner, 2019):

1. All life forms are characterized by semiosis, that is: processes, activities or conduct which involve the production and interpretation of codes, signals and signs. This means that the semiosic/non-semiosic distinction is coextensive with the life/nonlife distinction, i. e. with the domain of general biology.

2. Life is a phenomenon characterized by a psycho-physical unity. This means that biosemiotics rejects substance dualism, such as cartesian body-mind dualism, but defends a perspectivist dualism: life can be grasped both from the outside (by observation) and from the inside (by understanding).

3. All semiotic elements, such as information, codes, signals, signs, their decoding, reading and interpretation are natural phenomena. This means that biosemiotics both opposes the reductionist physicalist naturalism of orthodox Neo-Darwinism (which rigidly equates nature with elementary matter) and the metaphysical speculations about life, as found in nineteenth century vitalism and, more recent, creationism.

4. Life is characterized by an emergent evolutionary history, in which the semiosis becomes increasingly more differentiated and more complex. This implies that not only organisms evolve in the course of time, but that evolution itself evolves as well.

Against the background of these four postulates, in the following I will make the claim that the reductionist illusions of the Modern Synthesis, which Noble criticizes in his target article, are to a large extent resulting from a mere syntactical notion of biological information. Although this notion, introduced by Shannon, has been applied with much success in information theory and computer technologies, it is too narrow to understand biological reality. Biosemiotics can help to clarify the problems identified by Noble, and offers a more adequate biological information concept, which not only may help to overcome these problems in the life sciences, but may also serve to integrate naturalscientific and humanities approaches to life.

From a biosemiotic perspective, information can be understood as a sign, i.e. as a phenomenon which has a syntactical, pragmatic and semantic dimension (cf. Morris, 1938). This means that we can define information as a sign that (1) occurs with a

\footnotetext{
${ }^{1}$ See the special issue of Biosemiotics on 'information in biosemiotics' (Vol. 6, issue 1, 2013).
} 
certain probability or frequency within a sequence or arrangement of physical events (syntactical order), which (2) contains the potential to modify the physical and/or mental behavior or actions of the receiving organ or organism in a particular way (pragmatic effect), and (3) which may have a specific reference and/or meaning for the recipient (semantic content) (De Mul, 1999, 79-84; Ropohl, 1986, 85).

A simple everyday example may illustrate this definition. If I read in the news paper that it's going to rain today, and I decide to take my umbrella with me, we can distinguish all three dimensions in this process of semiosis. The ink dots on the paper (or pixels on the screen) are ordered in a specific sequence, constituting an encoded message (e.g. in the English language), with a referent (the weather outside) and meaning (its rainy condition), which motivates me to a specific action (taking my umbrella with me when I leave the house).

Of course, in order to be successful, the process of semiosis has to meet specific conditions. The recipient must be able to understand and/or handle the code. If the weather forecast is written in Chinese, if I don't have an umbrella, or if I don't know how to interpret the message, semiosis may fail. ${ }^{2}$ However, the semiotic concept of information is not restricted to arbitrary codes (symbols in the Peircean meaning of the word). The weather forecast in the Chinese newspaper may contain the international 'rainy weather' icon (based on a likeness or analogy), which would enable me to grasp at least part of the message. Or, looking out of the window of my hotel in Beijing, I may see raindrops on it, functioning as indices (signs causally connected with their referent, the shower outside). This example also shows that these different types of signs are not mutually exclusive, as the rain on the window, has an iconic relationship with the rain as well.

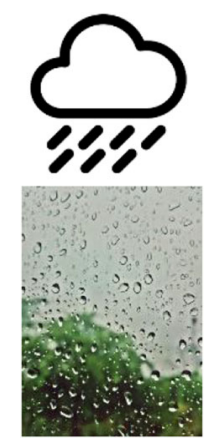

According to the first biosemiotics postulate, the starting point is that the basic unit of life is not the molecule, but the sign (Hoffmeyer, 1996). Life is a living sign, and taking the three aforementioned dimensions of the sign in consideration, three different processes of semiosis can be distinguished (Barbieri, 2009, 234; De Mul, 2015). Living

\footnotetext{
${ }^{2}$ In the three cases mentioned, there is respectively a syntactic, pragmatic and semantic failure of the semiosis. For a fascinating analysis of semantic failure, see Derrida's reflections on the phrase "Ich habe meinen Regenschirm vergessen," which - including the quotation marks - was found in Nietzsche's unpublished manuscripts. Although the syntactic code (the German language) was known to the publishers of Nietzsche's collected work, the semantic meaning was undecidable. Is it a quote? A reminder? Part of an unfinished aphorism? Can the sentence be considered part of Nietzsche's oeuvre? The semantic undecidability also caused pragmatic uncertainty for the editors: should the sentence be included in the collected works of Nietzsche or not? (Derrida, 1979, 122ff.).
} 
signs are about: (1) manufacturing objects (syntactical dimension); (2) assembling these objects into functioning structures (pragmatic dimension); and (3), interpreting the world (semantic dimension).

However, as the fourth postulate states, the living sign has an emergent, evolutionary history. It probably started with the manufacturing of objects by self-replication, as we find it - for example - in clay crystals, which show a successful transfer of a syntactical order (the regular lattice of atoms), but this transfer is not yet accompanied by a change in behavior or meaning. In other words, here we find syntactic semiosis only, i.e. the transfer of syntactic information. Although the clay crystal sign shows (indexical and iconic) reproduction, it is as lifeless as the transfer of a sequence of electric signals through a wire or electronic circuit. However, this syntactic notion of information (also known as Shannon information) was adopted by Crick in his description of the DNA code, which became known as Crick information.

On the one hand, this was a brilliant adaption, because the fascinating thing about DNA is that, unlike self-replicating clay crystals, the translation of messenger RNA-triplets into the amino acids in the protein - the core of manufacturing semiosis - is based on a code consisting of arbitrary symbols. ${ }^{3}$ In Howard Pattee's words: "Life is matter controlled by symbols" (Pattee, 1968, 157). According to the second postulate, process can be described both as a chemical process (from the outside) and as the transfer of a 'message' (from the inside).

So far, so good. However, inspired by the analogy with computer code, Crick understood the genetic code to be an algorithm that connects the 64 RNA triplets to the 20 amino acids. As Noble explains in his target article, this has inspired later molecular biologists like Jacob and Monod to call DNA a "genetic programme" and a "digital code". Noble offers several reasons why this "Fallacy of Digitalism" is problematic, which I don't have to repeat here. ${ }^{4}$ What is important in this context is Noble's argument that the self-replication of DNA always involves the control of the complete cell, outside the cell it is just dead matter. If we want to stick to a computer metaphor, Noble repeatedly emphasizes in The Music of Life. Biology Beyond Genes, DNA is a passive database rather than a program (Noble, 2006, xii, 3, 10, 15, 21 etc.). However, in The Music of Life Noble prefers semiotic terminology by comparing DNA to a musical score, which needs instruments (cells), sections of musicians (organs) and a composer (evolution) to be played (Noble, 2006).

We are dealing here with what can be referred to as signaling semiosis (Barbieri, 2009, 234). In a Peircean terminology, only within the whole of life functions does the organism become a pragmatic living system (Witzany, 2014). The pragmatic character of organic information systems lies in the fact that they adapt their behavior on the basis of a variety of

\footnotetext{
${ }^{3}$ See Noble's description in his target article of how different DNA triplet sequences correspond to the same amino acid.

${ }^{4}$ From a biosemiotics perspective, it could be added that not only the rest of cell is best viewed as analogue data, as Noble remarks, but also the DNA itself, because its function is not only depending on the sequence of its 'four letters' (the arbitrary symbols made out of nucleotides), but on its spatial structure as well. The semiosis of DNA is not only an example of a symbolic replication, but an iconic replication as well. In the case of epigenetic inheritance, for example, when a methyl group attaches itself to one of the nucleotides (cytosine), the DNA sequence remains the same, but the changing pattern of inheritance is connected to the spatial change. The two molecular structures can only be called the same on the basis of a Platonic abstraction of chemical reality, by equating DNA with a four-letter code (Dupré, 2015).
} 
signals about changes in the inner and outer world. Although the elementary processes can still be described and explained (causally) in syntactic terms, these processes have now been incorporated into an efficient system by means of various feedback loops, in which they perform all kinds of emergent behavior, which are no longer exclusively understandable in causal terms, but require a functional explanation. For example, the rhythm of the heart can only be understood in the light of the function that this rhythm has within the functioning of the heart, and of the function that the heart has in the body as a whole (Noble, 2017, 83-86).

On basis of the second postulate, signaling semiosis can be viewed from two perspectives, too. Seen from the outside, we see a functional whole, interacting with its environment. Understood from within, we understand intentional behavior. This already is the case with unicellular organisms. Bacterial movement to a nutrient like sugar can be described both as a chemical process (chemotaxis) and as the movement of an intentional system (Kauffman, 2008, 78). And if I reach out my hand reaches to grasp the umbrella before I leave the house, function and - in this case conscious intention again are the two sides of the same psycho-physical coin.

This signaling function plays a crucial role in downward causation and biological relativity. Downward causation - wittily described by Bitbol as "impossible as a concept, but [] well established as a fact" (Bitbol, 2012) - should not be understood as a new elementary force in addition to the causal forces already present in the constituent elements, but rather consists in the organization of these basic causal forces with the help of the signals provided by the tissue, organ or organism (Noble, 2017, 80-81; Van Gulick, 1995). Just as there is no privileged perspective to describe organic behavior, there is no privileged level of causality (Noble, 2017, 169).

Now different types can be distinguished with regard to downward causation (Ellis, 2009). The thermostat is an example of a non-adaptive form of downward causation, since the constituent forces and the goal - implemented in this case by a designer - are in principle not subject to change. Change is possible, however, in adaptive forms of downward causation, as we find them in living nature. After all, (unintentional and intentional) mutations constantly cause variations in the genetic material, whereby in the process of natural selection the variations that are better adapted to the environment survive and less adapted variations disappear. Thanks to self-organization, the organism can even adapt the selection criteria to new contexts. Moreover, in what Ellis calls "adaptive informational control", the goals pursued by the organism are no longer (purely) the result of natural selection. Through learning processes the organism can anticipate future situations and choose between different goals (feeding, flight, protection of offspring, etc.).

As Noble explains in Dance to the Tune of Life, in human beings, the downward causality takes a new flight through the emergence of (self) consciousness, symbolic representation and reasons (Noble, 2017, 180). Here downward causation takes the form of conscious (self) control (De Mul, 2019; Murphy et al., 2009). It is here that biological information acquires a semantic dimension and becomes the subject of interpretive semiosis, as we find it executed by humans (Barbieri, 2009, 234). These symbolic sign systems not only makes it possible to store experiences from the past and better anticipate the future, but they also enable us to imagine all kinds of non-existent situations and by semantic recombination invent new goals.

Once more we need the dual perspective on life in order to grasp the phenomenon in its fullness. Whereas the 'how' of this semantic dimension is researched from the outside by the neurosciences ('brain talk'), humanities scholars access his new 
emergent dimension of life from within. As was the case with previous forms of downward causation, this emergent subject of action is not to be explained as a new elementary causal power, but rather as a new level of control. Downward causation here takes the form of leading your life (i.e. organizing the life forces inside and outside us) with the help of meaningful - artistic, religious, scientific - narratives, which consist of a fabric of motives, reasons and values. On this level we are able to answer 'why' questions about our life, although there is no answer to the final why of the contingency of life.

Open Access This article is licensed under a Creative Commons Attribution 4.0 International License, which permits use, sharing, adaptation, distribution and reproduction in any medium or format, as long as you give appropriate credit to the original author(s) and the source, provide a link to the Creative Commons licence, and indicate if changes were made. The images or other third party material in this article are included in the article's Creative Commons licence, unless indicated otherwise in a credit line to the material. If material is not included in the article's Creative Commons licence and your intended use is not permitted by statutory regulation or exceeds the permitted use, you will need to obtain permission directly from the copyright holder. To view a copy of this licence, visit http://creativecommons.org/licenses/by/4.0/.

\section{References}

Barbieri, M. (2008). What is biosemiotics? Biosemiotics, 1(1), 1-3.

Barbieri, M. (2009). A short history of biosemiotics. Biosemiotics, 2(2), 221-245.

Bitbol, M. (2012). Downward causation without foundations. Synthese, 185, 233-255.

De Mul, J. (1999). The informatization of the worldview. Information, Communication \& Society, 2(1), 6994.

De Mul, J. (2015). The syntax, pragmatics and semantics of life. Reading Dilthey in the light of contemporary biosemiotics. In C. Damböck \& H. U. Lessing (Eds.), Dilthey als Wissenschaftsphilosoph (pp. 156-175). Verlag Karl Alber.

De Mul, J. (2019). The emergence of practical self-understanding. Human agency and downward causation in Plessner's philosophical anthropology. Human Studies, 42(1), 65-82.

Derrida, J. (1979). Spurs : Nietzsche's styles = Eperons : les styles de Nietzsche. University of Chicago Press.

Dupré, J. (2015). The polygenomic organism. In S. S. Richardson \& H. Stevens (Eds.), Postgenomics : Perspectives on biology after the genome (p. 5672). Duke University Press.

Ellis, G. F. R. (2009). Top-down causation and the human brain. In N. C. Murphy, G. F. R. Ellis, \& T. O'Connor (Eds.), Downward causation and the neurobiology of free will (pp. 63-81). Springer-Verlag.

Hoffmeyer, J. (1996). Signs of meaning in the universe. Indiana University Press.

Kauffman, S. A. (2008). Reinventing the sacred: A new view of science, reason and religion. Basic Books.

Kull, K., Deacon, T., Emmeche, C., Hoffmeyer, J., \& Stjernfelt, F. (2009). Theses on biosemiotics. Prolegomena to a theoretical biology. Biological Theory, 4(2), 167-173.

Morris, C. W. (1938). Foundation of the Theory of signs. University of Chicago Press.

Murphy, N. C., Ellis, G. F. R., \& O'Connor, T. (2009). Downward causation and the neurobiology of free will. Springer-Verlag.

Noble, D. (2006). The music of life. Biology beyond genes. Oxford University Press.

Noble, D. (2017). Dance to the tune of life. Biological relativity. Cambridge University Press.

Pattee, H. H. (1968). The physical basis of coding and reliability in biological evolution. In C. H. Waddington (Ed.), Towards a theoretical biology 1. Prolegomena (pp. 67-93). Edinburgh University.

Plessner, H. (2019). Levels of organic life and the human (M. Hyatt, Trans.). Fordham University Press.

Ropohl, G. (1986). Information does not make sense, or: The relevance gap in information technology and its social dangers. In C. Mitcham \& A. Huning (Eds.), Philosophy and technology II: Information technology and computers in theory and practice (pp. 63-74). Reidel.

Shannon, C. E. (1948). A mathematical theory of communication. Bell System Technical Journal, 27(379423), 623-656. 
Van Gulick, R. (1995). Who's in charge here? And who's doing all the work? In J. Heil \& A. Mele (Eds.), Mental Causation (pp. 233-256). Clarendon Press.

Watson, J. D., \& Crick, F. H. C. (1953). A structure for deoxyribose nucleic acid. Nature, 171, 737-738.

Witzany, G. (2014). Pragmatic turn in biology: From biological molecules to genetic content operators. World Journal of Biological Chemistry, 5(3), 279-285.

Publisher's Note Springer Nature remains neutral with regard to jurisdictional claims in published maps and institutional affiliations. 